\title{
Satellite Monitoring of Dramatic Changes at Hawai'i's Only Alpine Lake - Lake Waiau on Mauna Kea Volcano
}

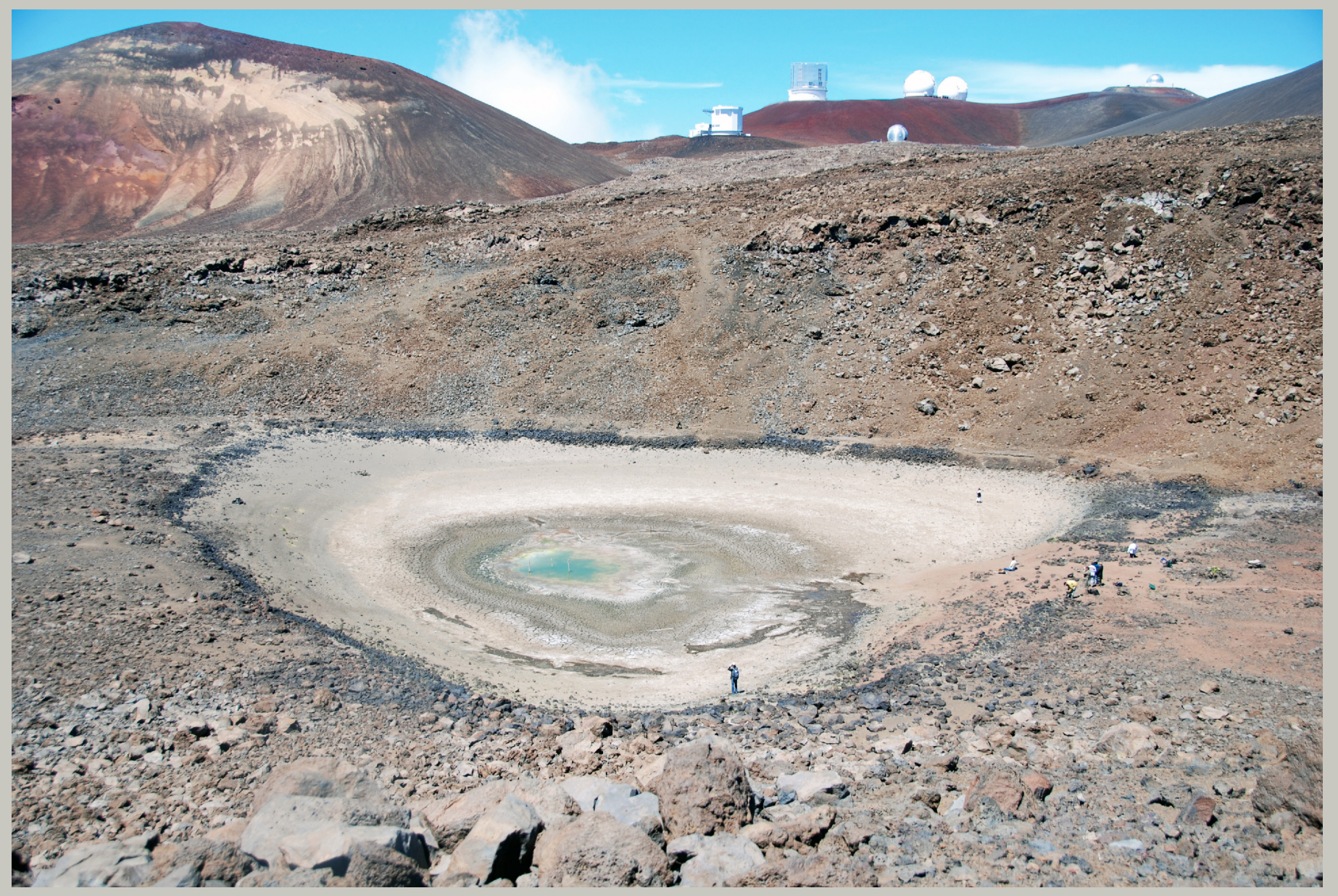

Scientific Investigations Report 2015-5076 
FRONT COVER

Photograph of Lake Waiau, near the summit of Mauna Kea volcano, Hawai'i, September 26, 2013. At this time the lake had nearly disappeared, with only a small, 10-meter-wide pool (green area) remaining at the bottom of the former lakebed. (U.S. Geological Survey photograph by Rebecca Rossi.) 


\section{Satellite Monitoring of Dramatic Changes at Hawai'i's Only Alpine Lake-Lake Waiau on Mauna Kea Volcano}

By Matthew R. Patrick and James Kauahikaua

Scientific Investigations Report 2015-5076 


\title{
U.S. Department of the Interior SALLY JEWELL, Secretary
}

\section{U.S. Geological Survey Suzette M. Kimball, Director}

\author{
U.S. Geological Survey, Reston, Virginia: 2015
}

For more information on the USGS - the Federal source for science about the Earth, its natural and living resources, natural hazards, and the environment-visit http://www.usgs.gov/ or call 1-888-ASK-USGS (1-888-275-8747).

For an overview of USGS information products, including maps, imagery, and publications, visit http://www.usgs.gov/pubprod/.

To order USGS information products, visit http://store.usgs.gov/.

Any use of trade, firm, or product names is for descriptive purposes only and does not imply endorsement by the U.S. Government.

Although this information product, for the most part, is in the public domain, it also may contain copyrighted materials as noted in the text. Permission to reproduce copyrighted items must be secured from the copyright owner.

Suggested citation:

Patrick, M.R., and Kauahikaua, J., 2015, Satellite monitoring of dramatic changes at Hawai'i's only alpine lake - Lake Waiau on Mauna Kea volcano: U.S. Geological Survey Scientific Investigations Report 2015-5076, 16 p., http://dx.doi. org/10.3133/sir20155076.

ISSN 2328-0328 (online) 


\section{Contents}

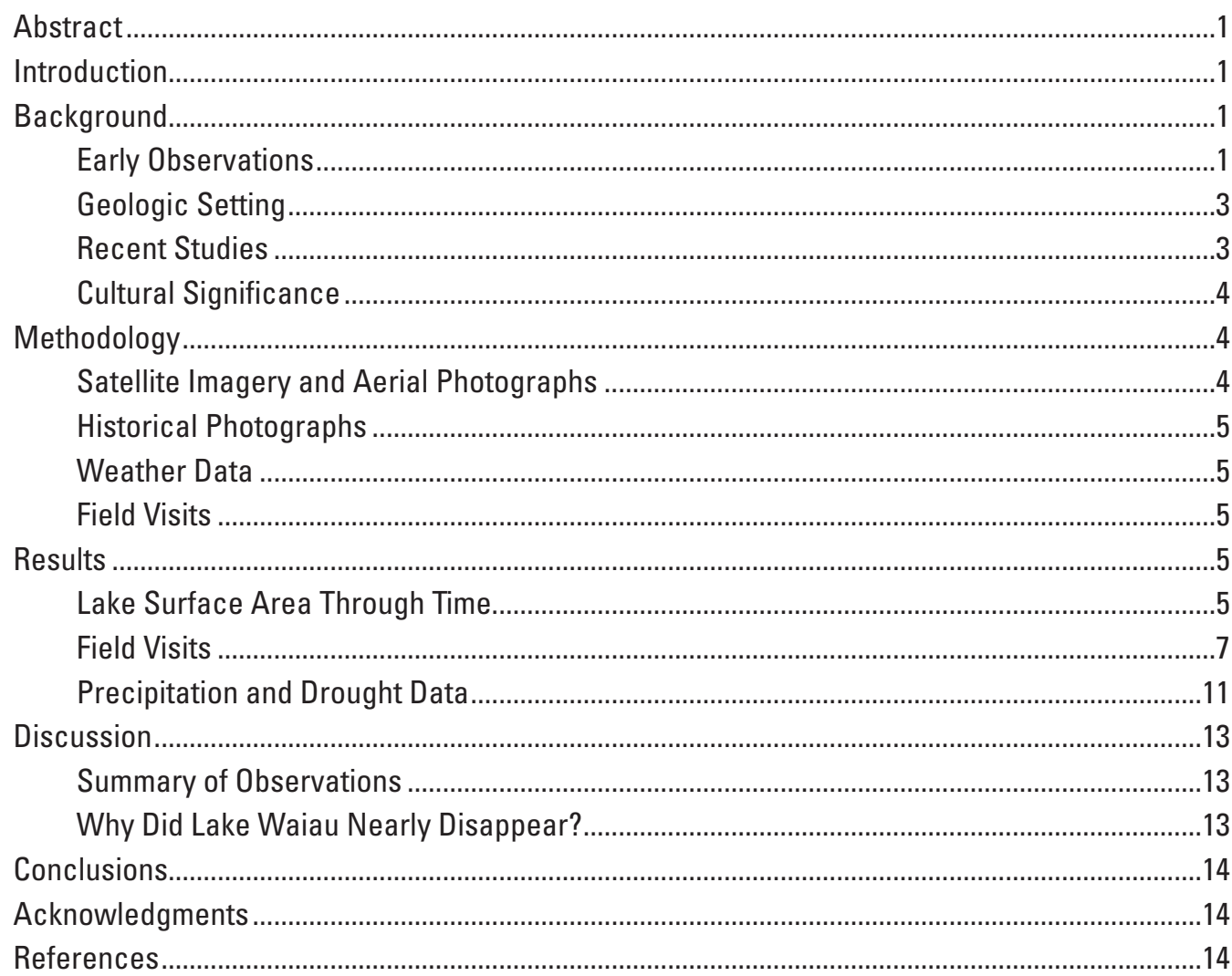

\section{Figures}

1. High-resolution satellite image of summit region of Mauna Kea volcano, Hawai'i...................2

2. Satellite images of Lake Waiau on Mauna Kea volcano, Hawai'i, before and after the reduction in lake size.

3. Satellite images during 2002-2014 showing changes in the size of Lake Waiau on Mauna Kea volcano, Hawai'i...

4. Graph of the measured surface area of Lake Waiau on Mauna Kea volcano, Hawai' $i$, 2000-2014. 9

5. Graph of the surface area of Lake Waiau on Mauna Kea volcano, Hawai'i, 1885-2014...........9

6. Photographs of Lake Waiau on Mauna Kea volcano, Hawai'i, on September 26, 2013...........10

7. Graph of precipitation data for Hale Pohaku weather station Hawai'i ....................................11

8. Graph comparing the surface area of Lake Waiau on Mauna Kea volcano, Hawai'i i.............12

9. Graph of drought data for the State of Hawaii from the National Drought Mitigation Center (2014).......

\section{Table}

1. Measurements of Lake Waiau on Mauna Kea volcano, Hawai'i. 



\title{
Satellite Monitoring of Dramatic Changes at Lake Waiau on Mauna Kea Volcano-Hawai'i'i's Only Alpine Lake
}

\author{
By Matthew R. Patrick and James Kauahikaua
}

\section{Abstract}

Lake Waiau is a small, typically 100 -meter-long lake, located near the summit of Mauna Kea volcano, on the Island of Hawai' $i$. It is Hawai'i's only alpine lake and is considered sacred in Hawaiian cultural tradition. Over the past few years, the lake has diminished in size, and, by October 2013, surface water had almost completely disappeared from the lake. In this study, we use high-resolution satellite images and aerial photographs to document recent changes at the lake. Based on our reconstructions covering the past 200 years, the historical lake surface area has typically ranged from 5,000 to 7,000 square meters, but in 2010 a dramatic plunge in lake area ensued. The lake area rebounded significantly in early 2014, following heavy winter storms. This near disappearance of the lake, judging from analysis of visitor photographs and field reports, appears to be highly unusual, if not unprecedented, in the historical record. The unusually low water levels in the lake are consistent with a recent severe drought in Hawai' $i$.

\section{Introduction}

Lake Waiau is a small body of water situated just below the summit of Mauna Kea volcano on the Island of Hawai' $i$ (fig. 1). It is one of the highest lakes in the United Statesat an elevation of 3,970 m-and is the only alpine lake in Hawai' $i$. The lake is sacred in Hawaiian tradition, as the summit of Mauna Kea is considered the "piko," or umbilical cord, connecting the Earth to the heavens (Maly and Maly, 2005).

The lake rests in the crater of $\mathrm{Pu}$ 'uwaiau, one of the many cinder cones around the summit region, and is bound on its north edge by the steep margin of a lava flow from $\mathrm{Pu}$ 'uhaukea. The island's water table is well below the level of the lake, which is a water body perched on a fine-grained sediment substrate (Woodcock, 1980). The lake is fed from precipitation, the majority of which originates from winter storms that bring sporadic rain and snow to these high elevations, falling in the Pu'uwaiau crater catchment basin (Ehlmann and others, 2005).

Before the recent changes we document here, Lake Waiau was triangular in shape, with the long axis (north-south) about 100 meters (m) (fig. 2A). Water level in the lake commonly fluctuated, depending on precipitation (Woodcock, 1980; Laws and Woodcock, 1981), and was approximately $3 \mathrm{~m}$ in depth at the deepest point. At maximum water level, lake water flowed into a small spillway gully on the western shore.

Recent field reports note a remarkable shrinking of the lake over the past few years, to sizes that are unusual in modern memory (fig. 2B; Patrick and Delparte, 2014; Delparte and others, 2014). For this study, we collected satellite images and aerial photographs of the lake to document recent changes and create a detailed time series of lake size. An assessment of climatic processes underlying recent changes in lake area was conducted using monthly precipitation data and drought conditions as estimated by the National Drought Monitor (National Drought Mitigation Center, 2014), which integrates climatic and hydrologic data along with reported field conditions in making drought declarations.

\section{Background}

The paragraphs below discuss early observations of Lake Waiau, its geologic setting, and recent scientific studies. The lake's cultural significance is also discussed.

\section{Early Observations}

Archaeological sites near Lake Waiau indicate that Hawaiians had been active in the area for centuries (Mills and others, 2008) before the arrival of the first Western visitors, who started going to the summit region of Mauna Kea in the early 1800s. The first recorded ascent of Mauna Kea by a Westerner was in 1823 by Missionary Joseph Goodrich (Goodrich, 1826), but he apparently did not visit the lake on this ascent (based on comments in Goodrich, 1834). Two other missionaries (Dr. Abraham Blatchley and Samuel Ruggles) climbed to the summit in 1824 and appear to have been guided by Goodrich (Maly and Maly, 2005). If Goodrich was the guide, this group did not visit Lake Waiau, based on later comments by Goodrich (Goodrich, 1834). In 1825 an ascent, guided by Goodrich, was made by members of Captain George Anson Byron's (7th Lord Byron) crew on the HMS Blonde, but no mention is made of the lake (Wilson, 1922). Missionary Hiram Bingham ascended the mountain with King Kamehameha III in 1830 and remarked, "We came to ... a pond of water partly covered with ice," which he also described as a "cold mountain lake" (Bingham, 1847). We assume this is a reference to Lake Waiau. Bingham's report 
is the first written record of Lake Waiau that we could find, although earlier instances may exist.

During a subsequent ascent by Goodrich, in 1832, he "found the pond or lake of water, of which I had frequently been informed" (Goodrich, 1834), suggesting numerous previous (but undocumented) visits to Lake Waiau. He estimated the lake to be 25 rods $(126 \mathrm{~m})$ in diameter. Members of the United States Exploring Expedition ascended to the summit in 1841 and, from previous reports, were aware of the existence of the lake but explicitly state that they did not visit it (Wilkes, 1844). A travel account published in the Pacific Commercial Advertiser in 1860 describes the lake as being "dried up" (Pacific Commercial Advertiser, 1860). There are two possible interpretations of this - (1) the lake was indeed dry or (2) the travelers did not visit the correct spot. If the lake was indeed dry, it is the only historical record in 200 years that we can find noting the lake's disappearance.
Clarence E. Dutton, the first geologist to visit Mauna Kea, does not mention Lake Waiau (Dutton, 1883). E.D. Baldwin visited the lake in August 1889 and noted that the lake was $200 \mathrm{ft}$ long by $150 \mathrm{ft}$ wide (Baldwin, 1889). Brigham (1909) shows an 1889 photograph of the lake with an area and water level appearing similar to that of most recent (pre-2010) images. The Preston and Alexander expedition to Mauna Kea in June 1892 noted that the lake was an acre and three quarters (that is, roughly 7,100 square meters, $\mathrm{m}^{2}$ ) in extent (Alexander, 1892). Charles H. Hitchcock visited in 1886 and again in July 1905, and his mention of the lake being " 125 feet long" appears to originate from the latter visit (Hitchcock, 1911).

A 1913 article in the Honolulu Star-Bulletin describes a visit by local hunters who seem to have been the first to measure the lake depth (Honolulu Star Bulletin, 1913). The article states that Lake Waiau was commonly said to be "bottomless." Using an iron weight and a system of lines strung

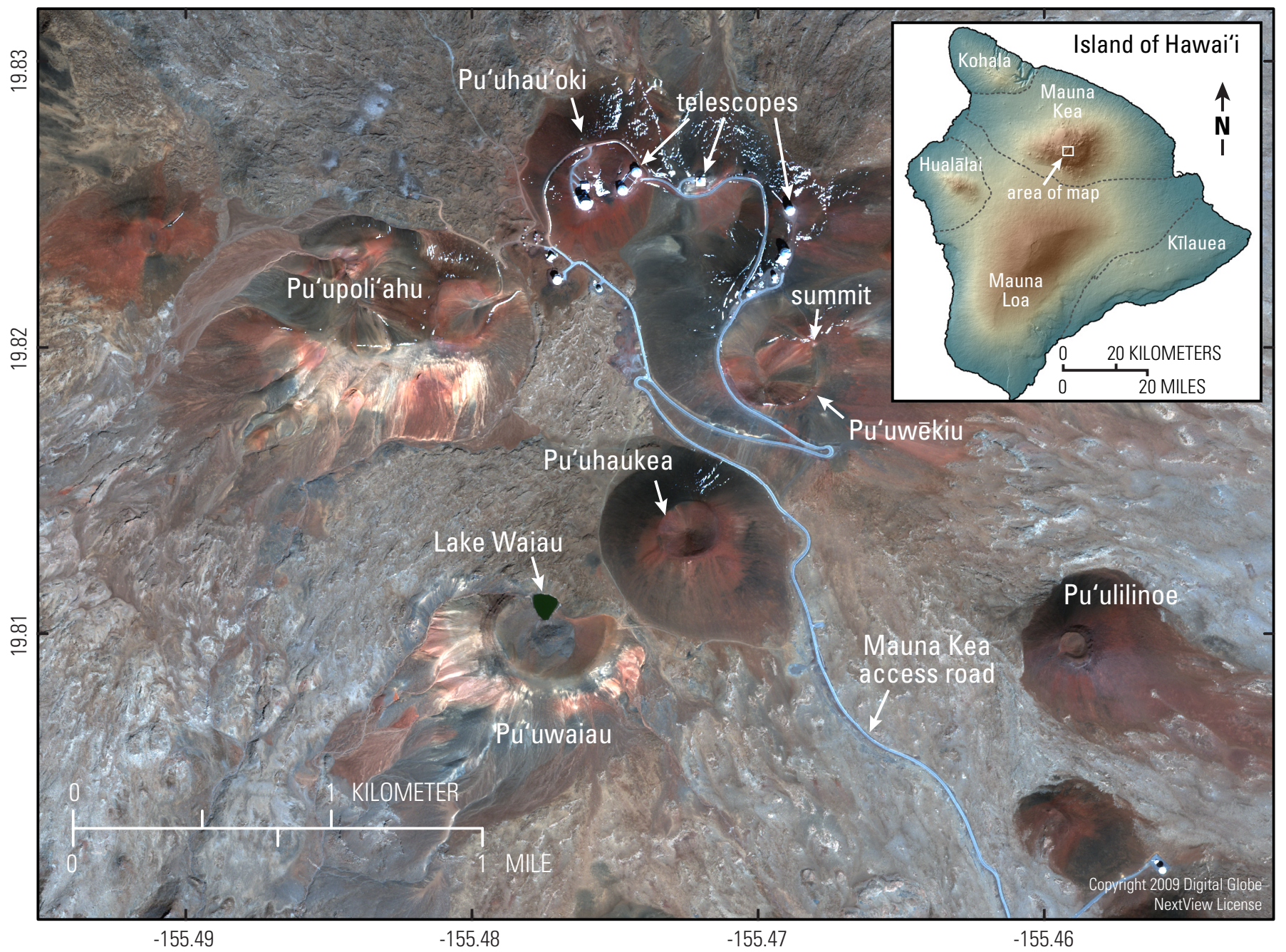

Figure 1. High-resolution satellite image of summit region of Mauna Kea volcano, Hawai' i. GeoEye 1 image, bands 3-2-1 (red-greenblue, RGB) from November 23, 2009. Image shows the position of Lake Waiau in relation to other prominent summit cinder cones and the summit access road. The true summit is atop Pu'uwēkiu, near several astronomical telescopes. Inset shows a shaded-relief map of the Island of Hawai'i. Dotted gray lines mark the surface boundaries between the five volcanoes that form the island. The small white box at the summit of Mauna Kea shows the footprint of the main image. 
across the lake, the hunters determined a maximum depth of 8 feet and 2 inches (relatively close to the maximum depth of about $3 \mathrm{~m}$ recorded in modern studies; Woodcock and others, 1980). They also measured the maximum and minimum dimensions of the lake as being $322 \times 290$ feet $(\mathrm{ft})(98 \times 88 \mathrm{~m})$. Bryan (1915) describes the lake as being "forty feet deep and several acres in extent" (this depth estimate cannot be accurate, based on recent studies noted below). Bryan (1939) stated that an increasing number of visitors had been making trips to the lake, owing to the new trail constructed by the Civilian Conservation Corps a few years earlier. A photograph in Bryan (1939) also appears to show the lake near its maximum water level.

\section{Geologic Setting}

Macdonald (1945) and Stearns and Macdonald (1946) established Mauna Kea's geologic framework, refined later by Wolfe and others (1997). The tholeiitic shield-building stage ended 200-250 thousand years ago (kiloannum, ka), followed by post-shield Hāmākua Volcanics and Laupāhoehoe Volcanics. The most recent volcanism on Mauna Kea occurred about 4,600 years before present (B.P.). (Wolfe and others, 1997; Sherrod and others, 2007).

Early geologists recognized that Mauna Kea had been covered by glacial ice (Daly, 1910). Further work showed that Mauna Kea had undergone several episodes of glaciation (Gregory and Wentworth, 1937; Wentworth and Powers, 1941). Porter (1979) refined the chronology of glacial activity and later presented evidence that some of the pyroclastic cones represent eruptions beneath an ice cap that covered the summit region (Porter, 1987). Peng and King (1992) dated sediments retrieved from a core taken beneath Lake Waiau extending back to $15 \mathrm{ka}$ (the carbon- $14,{ }^{14} \mathrm{C}$, age of $13 \mathrm{ka}$ in Peng and King was converted to years B.P. of $14.9 \pm 1.3$ ka by Pigati and others, 2008), suggesting that a topographic basin, and perhaps the lake, extended back to that time. These studies do not appear to mention any hiatus in the sediment record that might indicate sustained periods of lake disappearance.

\section{Recent Studies}

Focused studies of the lake and its surroundings began in the late 1960s with work by Woodcock and others (1966). Sediments extend more than $7 \mathrm{~m}$ below the base of the lake, incorporating several layers of tephra from nearby pyroclastic eruptions and estimated to be as old as the Pleistocene (Woodcock and others, 1966). In late 1969, an area of permafrost, extending down at least $10 \mathrm{~m}$, was discovered near the summit by Woodcock and others (1970) and was described in detail by Woodcock (1974). A detailed study by Woodcock (1980) showed that Lake Waiau water levels were sensitive indicators of precipitation, probably due to the frequency of winter storms that supply much of the water to the lake. The water is perched in the lake due to a layer of fine sediments (Woodcock 1980; Wolfe and others, 1997). By comparing tritium concentrations in springs at the base of Mauna Kea with those of the lake, as well as the groundwater around the lake, Woodcock (1980) proposed a conceptual model whereby groundwater

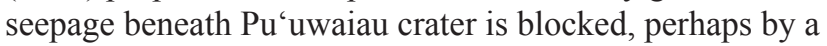
subsurface layer of permafrost, allowing the crater to act as a catchment basin, supplying water to the lake. Woodcock (1980) speculated that downward heat flow from the lake had melted the permafrost immediately beneath the lake and that some water from the lake was lost by seepage that then directly fed the springs low on Mauna Kea. Peng and King (1992) improved dating of cores of sediment from beneath the lake and showed that the sediment extended back as far as 15 ka (Pigati and others, 2008), suggesting that the lake may have existed that long. More recently, a hydrologic model developed by Ehlmann and others (2005) studied the water balance of the lake. Winter storms bring the primary input into the lake
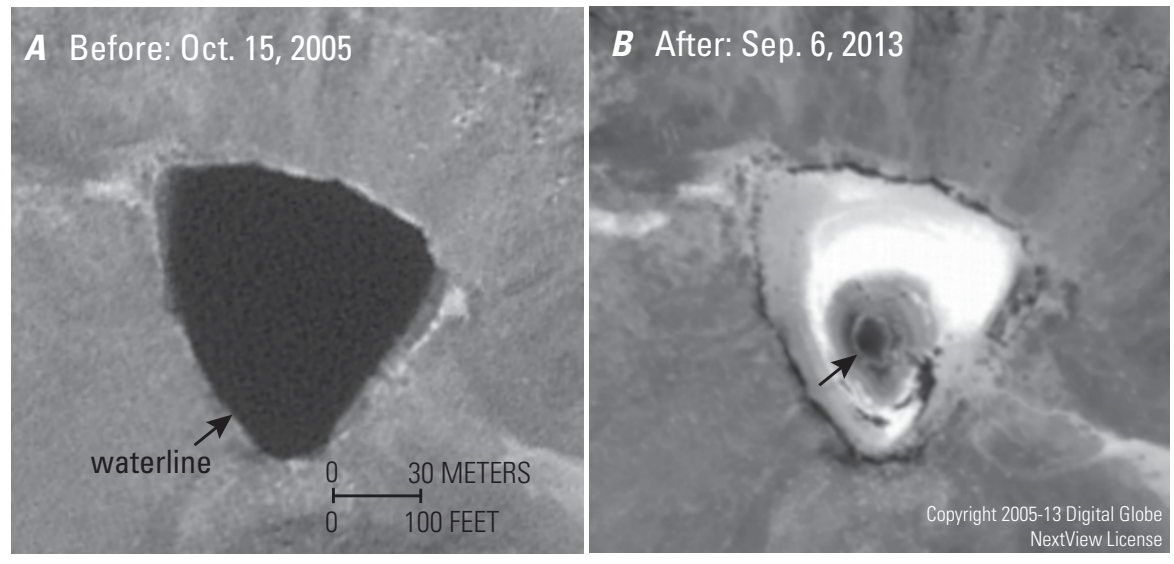

Figure 2. Satellite images of Lake Waiau on Mauna Kea volcano, Hawai'i, before and after the reduction in lake size. The arrow marks the waterline in both images. $A$, An Orbview satellite image from 2005, when the lake was about 100 meters $(\mathrm{m})$ long (north-south direction). B, WorldView 2 panchromatic satellite image of the lake from 2013 when it had nearly disappeared and was only about $15 \mathrm{~m}$ long. The light colored area is dry lakebed, and dark colored spots represent active seeps. See figure 6 for field photos taken around the same time as $B$. Outflow gulley is notch at northwest corner of lake. North at top in both images. 
and provide a light signature in oxygen and hydrogen isotopes, whereas summers show evaporation and loss, enriching the lake with heavy isotopes.

\section{Cultural Significance}

Waiau means "swirling water of a current" in the Hawaiian language (Pukui and Elbert, 1986). Beyond its scientific importance, the lake and surrounding summit area play significant roles in Hawaiian history and culture. Maly and Maly (2005) summarizes the cultural role of the summit region and the lake. In Hawaiian tradition, Mauna Kea is the piko, or umbilical cord, connecting the Earth to the heavens. Thus, the summit area is considered to be one of the most sacred spots in the Hawaiian Islands. Lake Waiau's water is believed to be particularly sacred, with healing abilities, and Hawaiians have placed the piko of their newborn children in the lake to ensure long life. In 1882, as Queen Emma Kaleleonālani was competing for the role of ruling chief in the Hawaiian kingdom, she made a pilgrimage to Mauna Kea's summit and ceremoniously bathed in the waters of Lake Waiau (Maly and Maly, 2005).

The Mauna Kea Comprehensive Management Plan (Office of Mauna Kea Management, 2009) and Mauna Kea Master Plan (University of Hawai'i, 2000) provide further background on the significance of the summit region.

Archaeological studies over the past few decades reinforce the cultural importance of the summit area (see review in Mills and others, 2008). McCoy (1999) surveyed dozens of archaeological sites, most of which were shrines, around Mauna Kea's summit. Many of these sites are clustered around the extensive adze quarries about $2 \mathrm{~km}$ south of Lake Waiau. These quarries were used over several centuries, and produced dense rock for stone tools. Mills and others (2008) state that the quarry complex is the largest known prehistoric quarry in the Pacific Basin.

\section{Methodology}

We used several methods to evaluate changes to the size Lake Waiau over the past 200 hundred years. These methods as described below included the examination of satellite and aerial imagery, historical photographs, weather data, and field visits to the lake.

\section{Satellite Imagery and Aerial Photographs}

Satellite data and vertical aerial photos of Lake Waiau were used to track lake surface area and lake dimensions. High-resolution satellite imagery was available back to about 2000, and included data from the IKONOS, Quickbird, WorldView, GeoEye, and OrbView sensors. We also used several Google Earth images of unknown origin, but these are often derived from Quickbird images. Image resolution ranged from 46 centimeters $(\mathrm{cm})$ to $1 \mathrm{~m}$, and we normally used the panchromatic bands, because they had higher resolution than the multispectral data. A total of 41 high-resolution images were available for the period between 2001 and 2014, providing a fairly detailed time series of recent lake changes.

Of the 41 satellite images, 8 had rational polynomial coefficient (RPC) files that enabled orthorectification (that is, georectification that removes terrain distortions). We orthorectified these images using the Shuttle Radar Topography Mission (SRTM) digital elevation model with Exelis ENVI 4.8 (see http://www.exelisvis.com/ProductsServices/ ENVIProducts.aspx). The remaining satellite images were then coregistered to one of these orthorectified satellite images. This georectification process was aided by using 36 waypoints, collected around the lake in June 2014, with a kinematic Global Positioning System (GPS) system. These waypoints were usually large boulders that were visible in the images. However, not all of the 36 waypoints were used for each image. We performed the georectification with Esri ArcGIS 9.3 (see http://www.esri.com/software/arcgis/), typically using a spline transformation (which requires a minimum of 10 corresponding points).

Aerial photographs were useful for tracking lake changes before 2000 , but unfortunately these data were much more sparse than the high-resolution satellite data. The aerial photos include a total of nine images between 1954 and 1995, with a large data gap through the 1980s. The aerial photos were coregistered with an orthorectified high-resolution satellite image (as described above).

Lake surface area was measured in the images manually in ArcGIS 9.3 using a polygon outline of the margin, and dimensions were measured using distances along the major north-south and east-west axes. In a few cases, a part of the lake margin was ambiguous, but our estimates show that the error in area of these ambiguities did not exceed a few percent. The largest source of error would be inaccurate georectification. Although the kinematic GPS points have an accuracy of several centimeters, and the high-resolution satellite images have a pixel size of $50 \mathrm{~cm}$, there was minor subjectivity in visually picking corresponding points that, we estimate, could produce as much as $2 \mathrm{~m}$ of uncertainty. If we assume that the georectification could be inaccurate by as much as $2 \mathrm{~m}$, the diameter measurements of the lake could have an error of as much as $4 \mathrm{~m}$. This 4-m error in diameter would be just 4 percent when the lake was at its maximum size (about 100 $\mathrm{m}$ wide) but as much as 25 percent when the lake area was minimal in late 2013 (when it was about $16 \mathrm{~m}$ wide). Taking the lake as a simple circle with a radius of $50 \mathrm{~m}$ during the pre-2010 period, the error in lake area would be up to approximately 8 percent. When the lake size was minimal (less than $200 \mathrm{~m}^{2}$ ), this error in area would be more than 50 percent. Nevertheless, as will be shown, the changes in lake size were sufficiently large that these potential errors do not affect the overall conclusions. 


\section{Historical Photographs}

A handful of historical photographs are available in the U.S. Geological Survey (USGS) Hawaiian Volcano Observatory (HVO) photograph archive, and these were useful for gauging the appearance of Lake Waiau back into the early 1900 s and late 1800s, particularly to judge whether any changes had occurred in the past that mimic those we see today. To judge water level and lake surface area in these old photographs, we used a simple, rough technique of comparing water levels between the old photographs and more recent images. If the shoreline level in the old photographs was roughly similar to the typical shoreline observed in recent (pre-2010) images, the pre-2010 range in surface area $(5,000$ $7,000 \mathrm{~m}^{2}$ ) was assigned to that date.

\section{Weather Data}

Precipitation data were downloaded from the National Oceanic and Atmospheric Administration (NOAA) National Climatic Data Center for the closest continuous weather station to Lake Waiau - at Hale Pohaku (Mauna Kea Visitor Center) - using the U.S. Annual Climatological Summary (http:// www.ncdc.noaa.gov/cdo-web/, most recent data in April 2014). The Hale Pohaku weather station is at an elevation of $2,822 \mathrm{~m}$, which is considerably lower than the elevation of the lake $(3,970 \mathrm{~m})$ but normally above the inversion layer (at an altitude of about 2,300 $\pm 500 \mathrm{~m}$ at Hilo; Cao and others, 2007) that maintains the dry conditions on Mauna Kea's upper slopes. Some precipitation data are available from weather stations at the summit astronomical telescopes (courtesy of Mauna Kea Weather Center, http://mkwc.ifa.hawaii.edu), much closer to the lake, but we could not find any continuous precipitation data on this site that included dates after 2010. Drought information for Hawai' $i$ was downloaded from the U.S. Drought Monitor Web site, maintained by the National Drought Mitigation Center (http://droughtmonitor.unl.edu).

\section{Field Visits}

On September 26, 2013, HVO geologists joined State of Hawaii Department of Land and Natural Resources personnel and Hawaiian cultural practitioners for a field visit to Lake Waiau to assess its low water level. Visual observations and photographs were taken of the lake, and physical measurements were taken with a Laser Technology TruPulse 360R laser rangefinder. Subsequent field visits were made on December 14, 2013, and June 20, 2014. During the latter visit, a kinematic GPS unit was used to mark the precise location of 36 features visible around the lake in the high-resolution satellite images. Approximately 1 minute of data was collected at each of the points, providing sub-meter position accuracy. These points were used to aid in georegistering the aerial images and unregistered satellite images.

\section{Results}

The following presents the results from our studies of Lake Waiau. These results include changes in the lake's surface area over time and results from field visits and the evaluation of precipitation and drought data.

\section{Lake Surface Area Through Time}

Figures 3 and 4 show the surface area of Lake Waiau during 2000 to 2014, based almost exclusively on high-resolution satellite data (table 1). From 2000 to late 2009, the lake's surface area fluctuated between 5,000 and $7,000 \mathrm{~m}^{2}$. This corresponds with north-south dimensions ranging from approximately 90 to $100 \mathrm{~m}$. Owing to steeper bounds on the north and south margins, most of the variation in size was accommodated along the east-west axis of the lake. At times of larger surface area, the west margin of the lake would be very close to, or at, the spillway gulley adjacent to the lake.

A decrease in the lake's surface area, below the typical range, began in 2010, bracketed by images on December 24, 2009, and September 29, 2010 (fig. 3). The former image shows the lake area within its usual range $\left(5,000-7,000 \mathrm{~m}^{2}\right)$, but the latter image is already below the typical range of variation, suggesting that an unusual shrinking phase had already begun by the latter date. From September 2010 to September 2013, the reduction in lake surface area followed a roughly linear trend, dropping $\sim 100 \mathrm{~m}^{2}$ per month. Even during the dramatic plunge in lake surface area following 2010, the lake did show seasonal variations consistent with previous behavior (Ehlmann and others, 2005). Superimposed on the decline are several small peaks (early 2011 and early 2012) that correspond with winter months, presumably representing recharge due to precipitation from winter storms.

Aerial photographs, along with a few field reports, show the state of the lake between 1935 and 2000 (fig. 5). Consistent with the 2000-2009 trend shown in the satellite data, the majority of surface-area measurements are between 5,000 and $7,000 \mathrm{~m}^{2}$, again suggesting that this is the typical historical range for the lake's area. One outlier is 1978, when surface area of the lake plunged to about $4,100 \mathrm{~m}^{2}$, which occurred during a drought (Woodcock, 1980).

Historical photographs push the time series back further. A photo in Brigham (1909) from 1889 shows the lake at a relatively full level, which we assume represents the lake's surface area in the typical pre-2010 range (5,000-7,000 $\left.\mathrm{m}^{2}\right)$. Photographs from 1885, 1892, 1914, and 1920 from the HVO archive also show the lake at a full level, and we assign the same lake area.

The estimates of the size of Lake Waiau that early visitors made are questionable but still useful for general insight. The estimate of 25 rods diameter (about $125 \mathrm{~m}$ ) in 1832 by Goodrich (1834) is almost certainly excessive, as the lake size is constrained by the topographic bounds and adjacent 
Table 1. Measurements of Lake Waiau on Mauna Kea volcano, Hawai'i.

$[--$, no data $]$

\begin{tabular}{|c|c|c|c|c|}
\hline Date & $\begin{array}{c}\text { North-south } \\
\text { length, } \\
\text { in meters }\end{array}$ & $\begin{array}{c}\text { East-west } \\
\text { length, } \\
\text { in meters }\end{array}$ & $\begin{array}{c}\text { Area, in } \\
\text { square meters }\end{array}$ & Source \\
\hline Aug. 1, 1935 & -- & -- & 6,070 & Gregory and Wentworth (1937) \\
\hline Oct. 19,1954 & 94 & 85 & 5,898 & Aerial photo \\
\hline Mar. 7, 1965 & 95 & 90 & 6,326 & Aerial photo \\
\hline Oct. 9, 1974 & 99 & 92 & 6,557 & Aerial photo \\
\hline Jul. 22, 1975 & 102 & 99 & 7,188 & Aerial photo \\
\hline Dec. 11,1976 & 95 & 86 & 6,053 & Aerial photo \\
\hline Jan. 1, 1977 & 98 & 84 & 6,118 & Aerial photo \\
\hline Dec. 1,1977 & 92 & 83 & 5,639 & Woodcock (1980) \\
\hline Oct. 1,1978 & 78 & 69 & 4,070 & Woodcock (1980) \\
\hline Sep. 23, 1992 & 101 & 93 & 5,841 & Aerial photo \\
\hline Sep. 30, 1992 & 100 & 84 & 5,641 & Aerial photo \\
\hline Sep. 7, 1995 & 96 & 86 & 6,091 & Aerial photo \\
\hline Aug. 1, 2000 & -- & -- & 6,000 & Ehlmann and others (2005) \\
\hline Apr. 27, 2001 & 95 & 82 & 5,532 & Google Earth \\
\hline Jan. 8, 2002 & 100 & 101 & 7,184 & Digital orthophoto quadrangle \\
\hline Dec. 26, 2002 & 101 & 92 & 6,614 & Quickbird 2 \\
\hline Sep. 29, 2003 & 92 & 82 & 5,499 & Orbview 3 \\
\hline Apr. 3, 2005 & 96 & 94 & 6,695 & Ikonos \\
\hline Apr. 30, 2005 & 98 & 93 & 6,735 & Ikonos \\
\hline Aug. 10, 2005 & 98 & 96 & 6,798 & Ikonos \\
\hline Oct. 15,2005 & 99 & 94 & 6,592 & Orbview 3 \\
\hline Dec. 2, 2005 & 98 & 95 & 6,658 & Orbview 3 \\
\hline Sep. 11,2006 & 97 & 96 & 6,746 & Google Earth \\
\hline Jan. 22, 2008 & 97 & 83 & 5,920 & Ikonos \\
\hline Jan. 25, 2008 & 97 & 88 & 6,072 & WorldView 1 \\
\hline Jul. 20, 2008 & 98 & 94 & 6,760 & WorldView 1 \\
\hline Sep. 2, 2009 & 99 & 97 & 6,955 & WorldView 1 \\
\hline Sep. 12, 2009 & 98 & 97 & 6,857 & Quickbird 2 \\
\hline Nov. 23, 2009 & 97 & 88 & 6,132 & GeoEye 1 \\
\hline Dec. 24, 2009 & 97 & 92 & 6,193 & Quickbird 2 \\
\hline Sep. 29, 2010 & 85 & 71 & 4,175 & WorldView 2 \\
\hline Nov. 23, 2010 & 73 & 61 & 3,116 & WorldView 1 \\
\hline Dec. 18, 2010 & 72 & 59 & 3,034 & WorldView 1 \\
\hline Jan. 14, 2011 & 73 & 60 & 2,951 & GeoEye 1 \\
\hline Mar. 18, 2011 & 80 & 66 & 3,646 & WorldView 2 \\
\hline Apr. 4, 2011 & 79 & 66 & 3,583 & WorldView 2 \\
\hline Sep. 8, 2011 & 61 & 48 & 2,124 & WorldView 1 \\
\hline Nov. 30, 2011 & 55 & 40 & 1,595 & WorldView 2 \\
\hline Dec. 27, 2011 & 70 & 55 & 2,780 & WorldView 2 \\
\hline May. 29, 2012 & 72 & 59 & 3,023 & WorldView 1 \\
\hline Jun. 18, 2012 & 64 & 51 & 2,337 & WorldView 2 \\
\hline
\end{tabular}


Table 1. Measurements of Lake Waiau on Mauna Kea volcano, Hawai'i.-Continued

\begin{tabular}{lcccl}
\hline \multicolumn{1}{c}{ Date } & $\begin{array}{c}\text { North-south } \\
\text { length, } \\
\text { in meters }\end{array}$ & $\begin{array}{c}\text { East-west } \\
\text { length, } \\
\text { in meters }\end{array}$ & $\begin{array}{c}\text { Area, in } \\
\text { square meters }\end{array}$ & Source \\
\hline Aug. 9, 2012 & 51 & 39 & 1,498 & WorldView 1 \\
Jan. 9, 2013 & 40 & 29 & 835 & Google Earth \\
Apr. 7, 2013 & 39 & 28 & 773 & WorldView 2 \\
May. 15, 2013 & 36 & 23 & 560 & WorldView 2 \\
Jun. 3, 2013 & 33 & 22 & 479 & WorldView 1 \\
Aug. 31, 2013 & 19 & 12 & 147 & WorldView 2 \\
Sep. 6, 2013 & 16 & 12 & 131 & WorldView 2 \\
Sep. 26, 2013 & 14 & 11 & 114 & Field measurement \\
Dec. 14, 2013 & 24 & 11 & 213 & Field measurement \\
Jan. 6, 2014 & 38 & 29 & 717 & WorldView 2 \\
Feb. 8, 2014 & 47 & 42 & 1,423 & WorldView 2 \\
Mar. 1, 2014 & 52 & 42 & 1,557 & WorldView 2 \\
Apr. 4, 2014 & 74 & 66 & 3,419 & WorldView 2 \\
\hline
\end{tabular}

spillway channel and cannot greatly exceed about $100 \mathrm{~m}$ in maximum dimension. The estimate of $200 \mathrm{ft}(60 \mathrm{~m})$ long by Baldwin (1889) is smaller than the recent typical length of the lake (90-100 m). Hitchcock (1911) estimated the lake as $125 \mathrm{ft}(40 \mathrm{~m})$ long, which is fairly small. Because these are rough estimates, there is no value in analyzing each one, but most describe the lake as having a size roughly consistent with more reliable values measured after 1930, and none indicate the vanishingly small sizes recorded in late 2013. Describing a 1924 visit, Harold Stearns noted that the lake "never goes dry" (Stearns unpublished journal, November 8, 1924, notebook 6, p. 207), and Bryan (1927) states that "Lake Waiau ... has never been known to run dry"; however, we cannot comment on the accuracy of these anecdotal statements. The 1860 observation of the lake's disappearance is possible but not certain. Overall, these early reports, combined with the more recent data (figs. $3,4,5$ ), suggest that the recent near-disappearance of the lake is highly unusual, if not unprecedented, in the historical record (which begins in about 1830 for Lake Waiau).

\section{Field Visits}

Our visit on September 26, 2013, confirmed that the lake was vanishingly small and that most of the former area of the lake was dry lakebed (fig. 6). The lakebed consisted of three zones:

1. Water-In the center of Lake Waiau was the remaining pool of water, which was very small and shallow. The water was greenish and did not seem to be more than $20 \mathrm{~cm}$ deep (based on the surrounding slope). Measurements along the two main axes of the water body were made with a laser rangefinder. The northsouth length ( $339^{\circ}$ azimuth) was $13.5 \mathrm{~m}$, while the east-west length $\left(73^{\circ}\right.$ azimuth) was $10.8 \mathrm{~m}$. Assuming a simple ellipse, the area is $114 \mathrm{~m}^{2}$. Sticking out of the water were a few pipes, which were presumably abandoned from previous coring of the lake sediment (Woodcock and others, 1966, or Peng and King, 1992).

2. Muddy zone-Surrounding the water was a zone of dark-brown ground with many mud cracks, and this appeared to be a partially wet, muddy zone. A few pipes stuck out of this zone, as well, and there was one pipe, about a meter or two long, resting on its side on the surface.

3. Dry lakebed-Surrounding the muddy zone, what appeared to be a dry lake surface formed most of the lakebed. The color of this dry lake area was tan, with rocks here and there sticking out of the ground or sitting on the surface. At least two tiny seeps, where water seeped up from below ground, were in the southeastern quadrant of the dry lake area. These seeps had small $(10 \mathrm{~cm}$ wide) pools of stagnant water that fed tiny, stagnant channels of water unconnected with the lake but which soaked into the ground. The seep areas were obvious, because the ground around them was dark brown, much like the appearance of the muddy zone around the lake. There appeared to be at least two other tiny seeps in the southern part of the lakebed as well. An abrupt break in slope seemed to correspond with the high waterline, and there is a line of dark rocks at this level. The overflow spillway at the northwestern corner of the lake represents the absolute high watermark of the lake. This spot was $3.0 \mathrm{~m}$ above the water level (measured by laser rangefinder), which means that the maximum depth of the lake is also about $3.0 \mathrm{~m}$. 

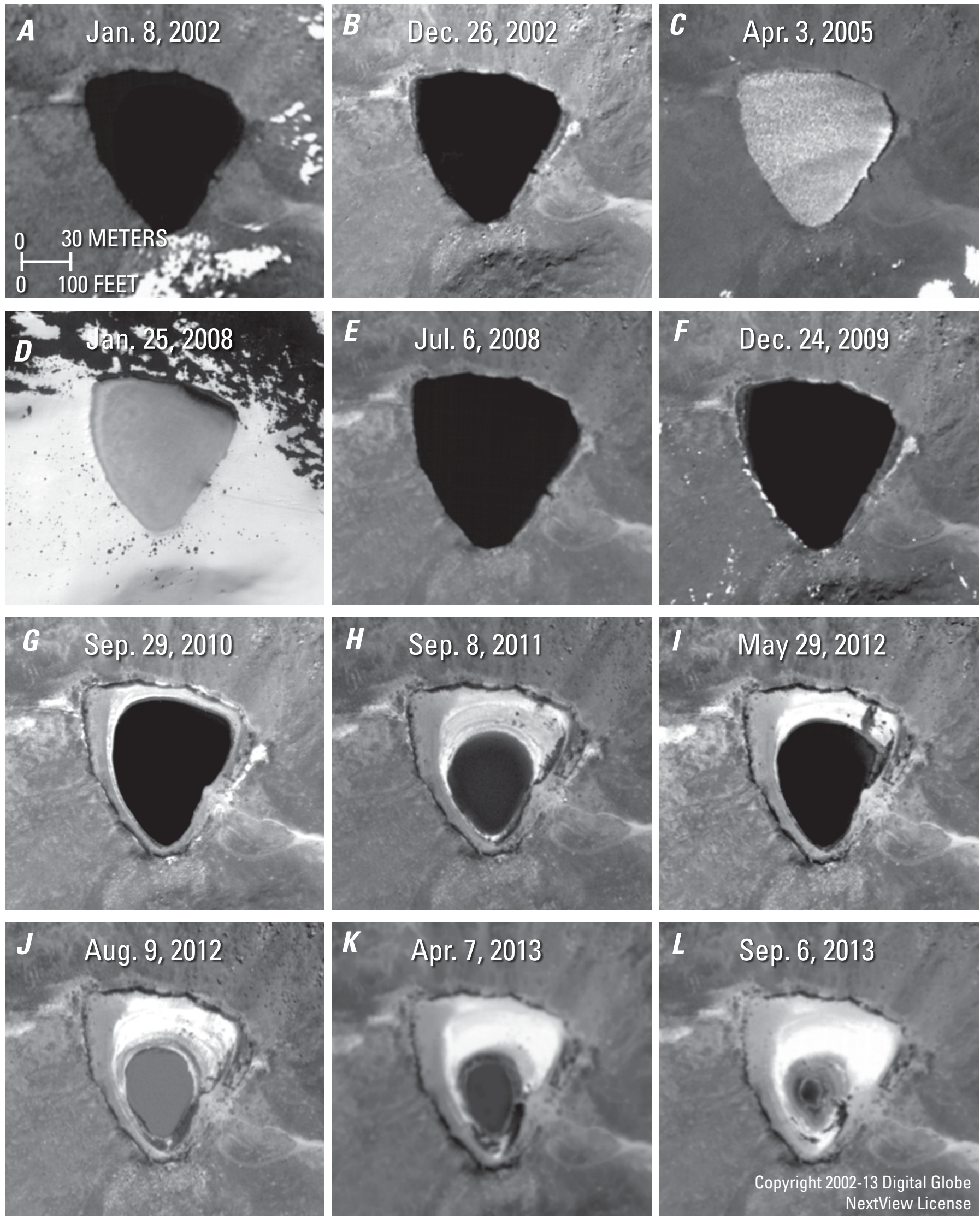

Figure 3. Satellite images during 2002-2014 showing changes in the size of Lake Waiau on Mauna Kea volcano, Hawai'i. A- $L$ show satellite images at the marked dates. Dramatic shrinking of the lake began in 2010, as bracketed by $F$ and $G$. North at top. 


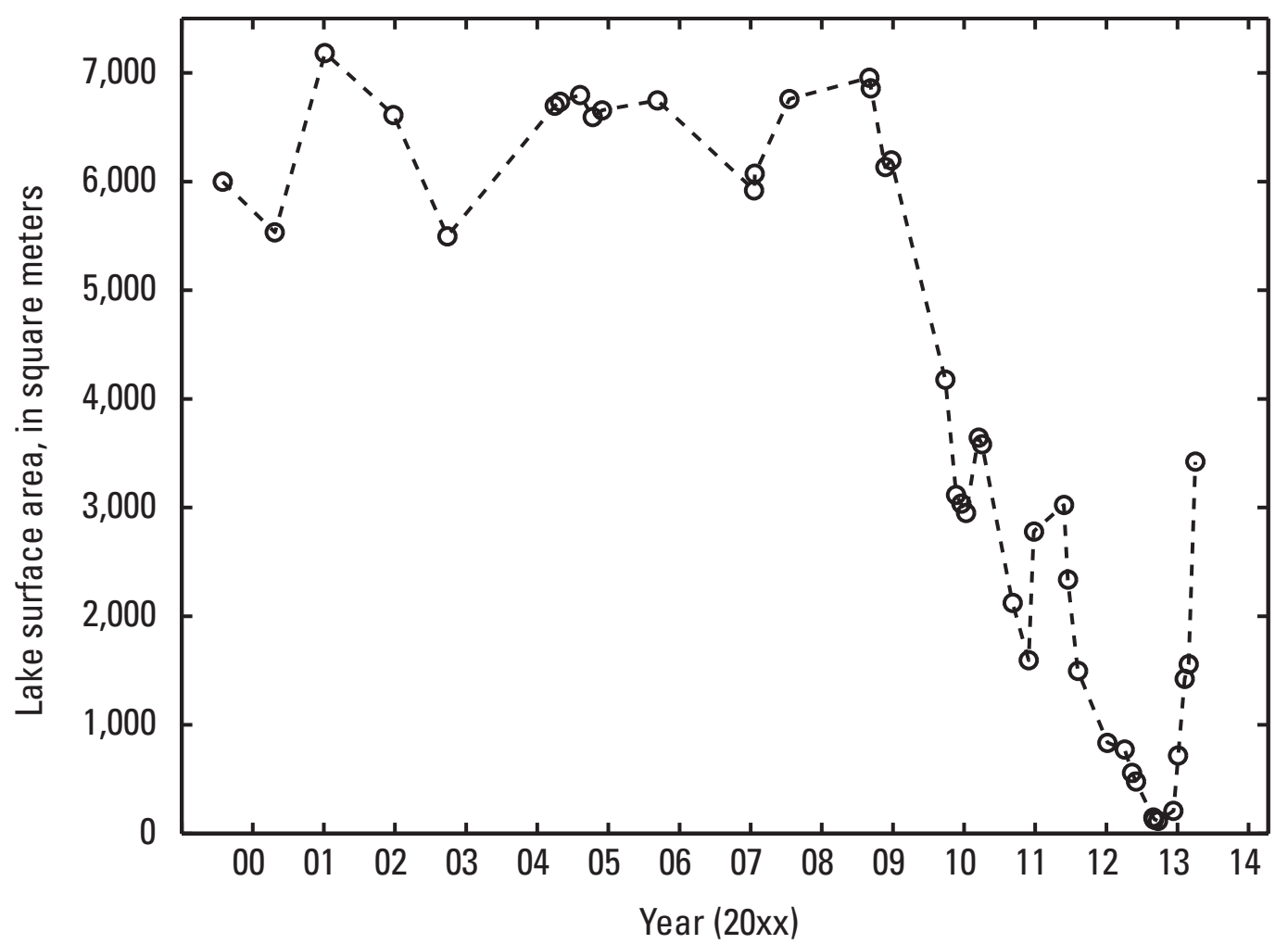

Figure 4. Graph of the measured surface area of Lake Waiau on Mauna Kea volcano, Hawai'i, 2000-2014. Most of these data points originate from high-resolution satellite images. The first data point (August 2000) originates from Ehlmann and others (2005), who stated a rough estimate of the surface area for that time.

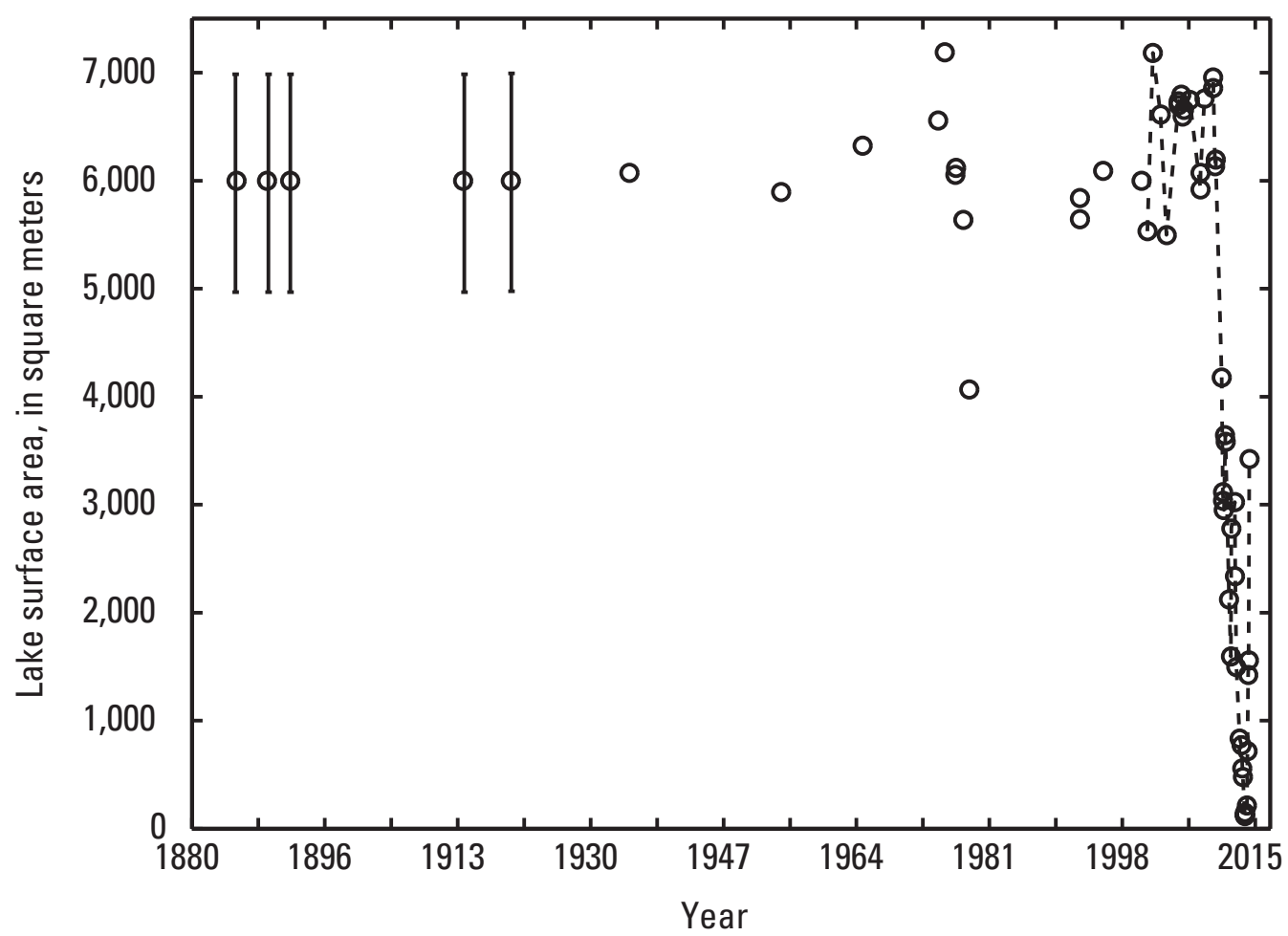

Figure 5. Graph of the surface area of Lake Waiau on Mauna Kea volcano, Hawai' i, 1885-2014. The first five data points originate from historical photographs showing the lake level consistent with recent (pre-2010) observations, which we interpret to represent a surface area within the lake's typical pre-2010 range (5,000-7,000 square meters) as indicated by error bars. Data points after 2000 are shown connected with a dotted line, but points before that year are not connected due to sparseness. 

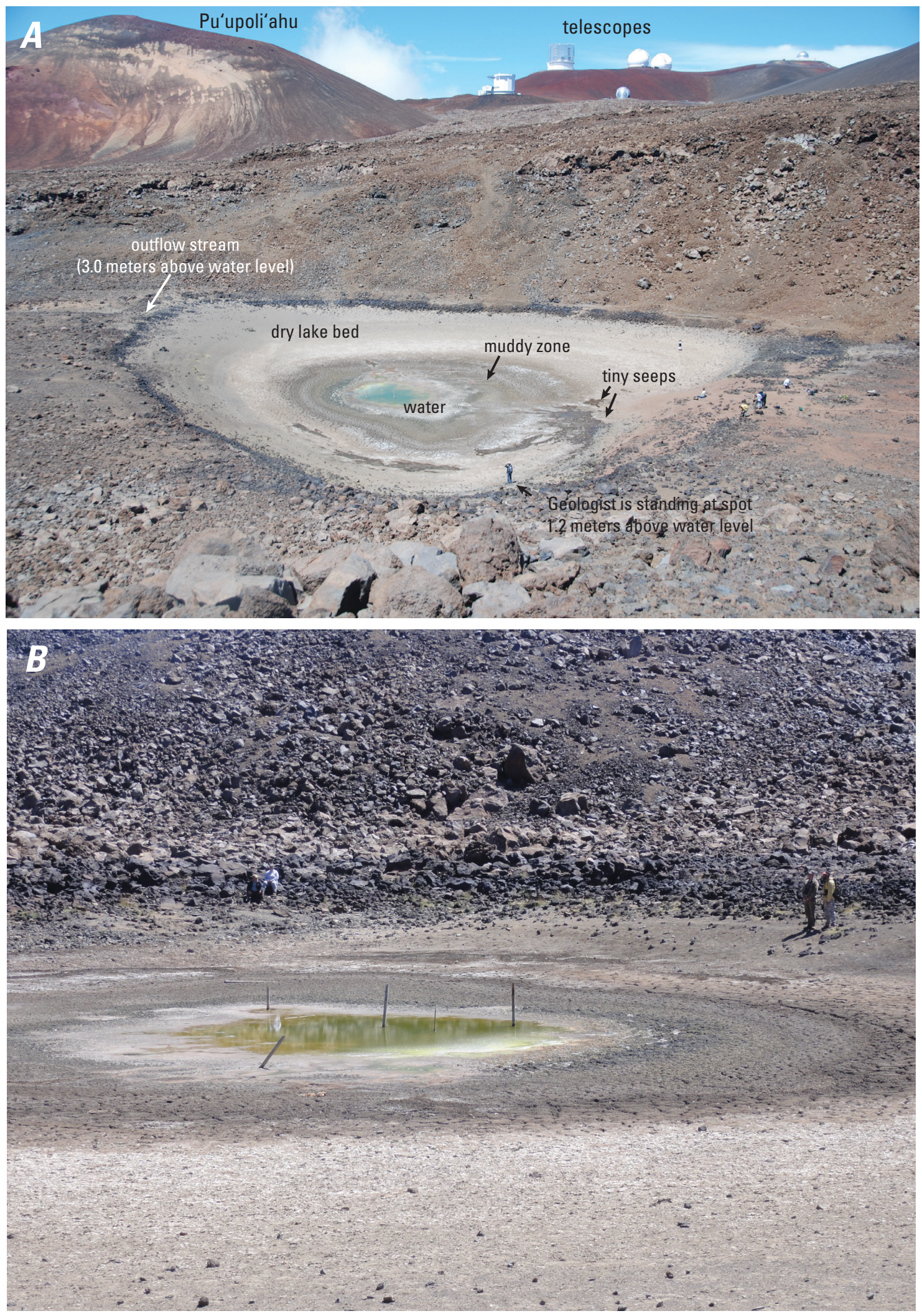

Figure 6. Photographs of Lake Waiau on Mauna Kea volcano, Hawai'i, on September 26, 2013, when the lake had nearly disappeared. $A$, View of the lakebed, looking north. Geologists are standing on the eastern shoreline for scale (U.S. Geological Survey photograph by Rebecca Rossi). B, Close-up view of the remaining lake water, looking south from the northern shoreline (U.S. Geological Survey photograph by Matthew Patrick). Geologists on the shoreline for scale. The pipes sticking out of the lakebed presumably represent casings from research drilling projects. 
The visit in December 2013 showed relatively similar conditions. The June 2014 field visit occurred after the early 2014 precipitation increase and lake level rebound. Although the lake size was still below the typical pre-2010 area of $5,000-7,000 \mathrm{~m}^{2}$, the lake appeared roughly similar to its pre2010 state.

\section{Precipitation and Drought Data}

Figure 7 shows precipitation data for Hale Pohaku (Mauna Kea visitor center) for 1940-2014, from NOAA's U.S. Annual Climatological Summary dataset (http://www. ncdc.noaa.gov/cdo-web/). The long-term trend in figure $7 \mathrm{~A}$ shows that yearly precipitation (up to 2013) on the upper slopes of Mauna Kea can be highly variable, ranging from less than 20 centimeters per year $\left(\mathrm{cm} \mathrm{yr}^{-1}\right)$ to more than 120

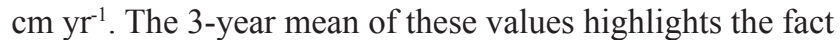
that unusually low values have been present since about 2007, consistent with the statewide drought that began in 2008, and that the 3-year mean reached unprecedented lows for the 70 -year period in 2011. Monthly data from 2000-2014 in figure $7 B$ show more detail for recent years. The large spikes in precipitation common during 2000-2005 are mostly absent after 2007, and after 2008, months of little to no precipitation become more common, again consistent with the recent drought. A large spike in early 2014 (when the data end) is consistent with several large winter storms that occurred in early 2014.

Figure 8 shows the correspondence between precipitation at Hale Pohaku and the surface area of Lake Waiau during the decline in lake area from 2010 to 2014. The overall declining trend in lake surface area has several distinct peaks (early 2011 and early 2012). The early 2011 and 2012 peaks appear to correspond to seasonal peaks in precipitation. The rebound in lake area in 2014 corresponds in time with a large spike in precipitation. This early 2014 precipitation included several winter storms that blanketed the summit area in snow. This correlation is consistent with the observations by Woodcock (1980), who showed that the lake level was sensitive to precipitation.

Data from the National Drought Mitigation Center shows the trend in drought conditions for the State of Hawaii since 2000 (fig. 9) (National Drought Mitigation Center, 2014). Elevated and sustained drought conditions began in 2008, with extreme drought (category D3) appearing in mid-2008 for roughly 30 percent of Hawai' $i$. This intensified in March 2010,

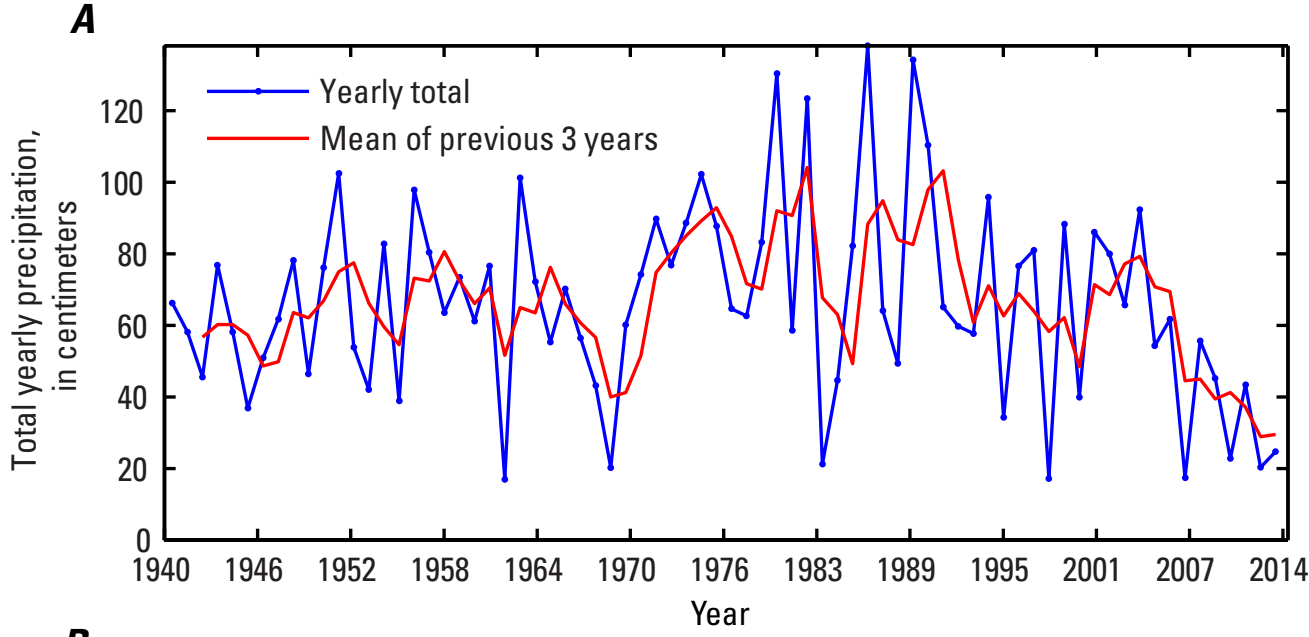

B

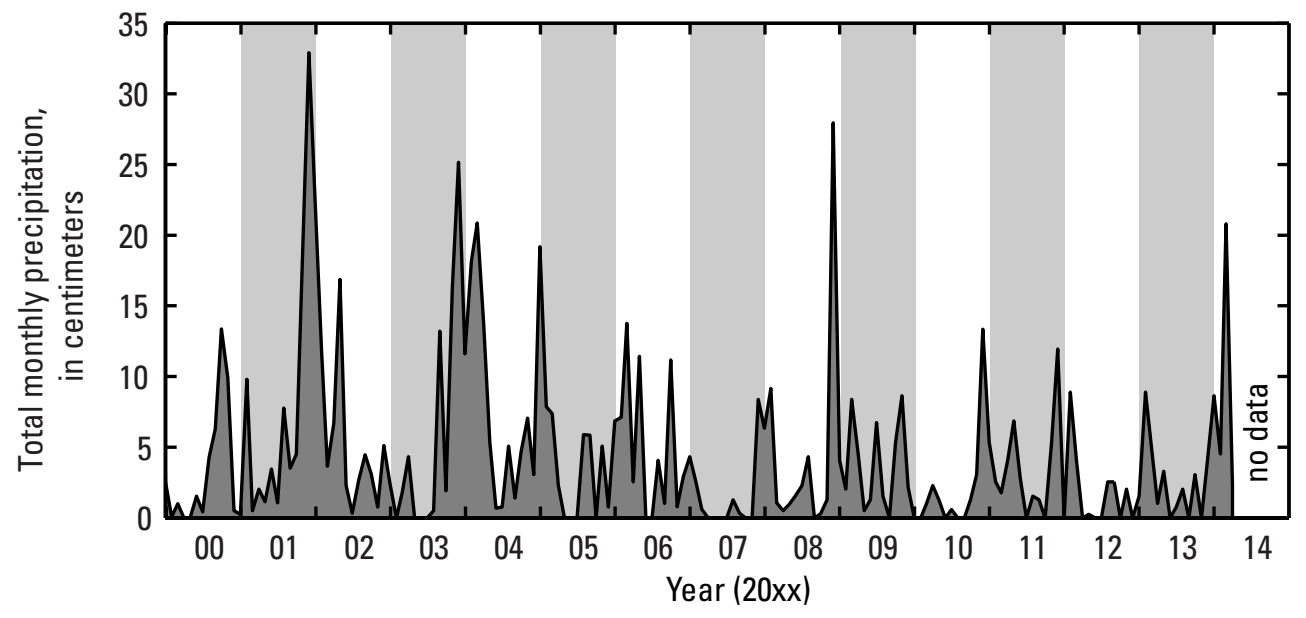

Figure 7. Graph of precipitation data for Hale Pohaku weather station (Mauna Kea Visitor Center, 2,822 meters above sea level), Hawai'i. $A$, Yearly precipitation data since 1940 (blue). The mean of the preceding 3 years is shown in red. Note the decline in the 3-year mean after 2006. $B$, Monthly precipitation data since 2000. Low (but not unprecedented over this time scale) values of precipitation were recorded in the first half of 2010, around the time that Lake Waiau began shrinking. Data from the National Oceanic and Atmospheric Administration (NOAA) U.S. Annual Climatological Summary (http:// www.ncdc.noaa.gov/cdo-web/). 


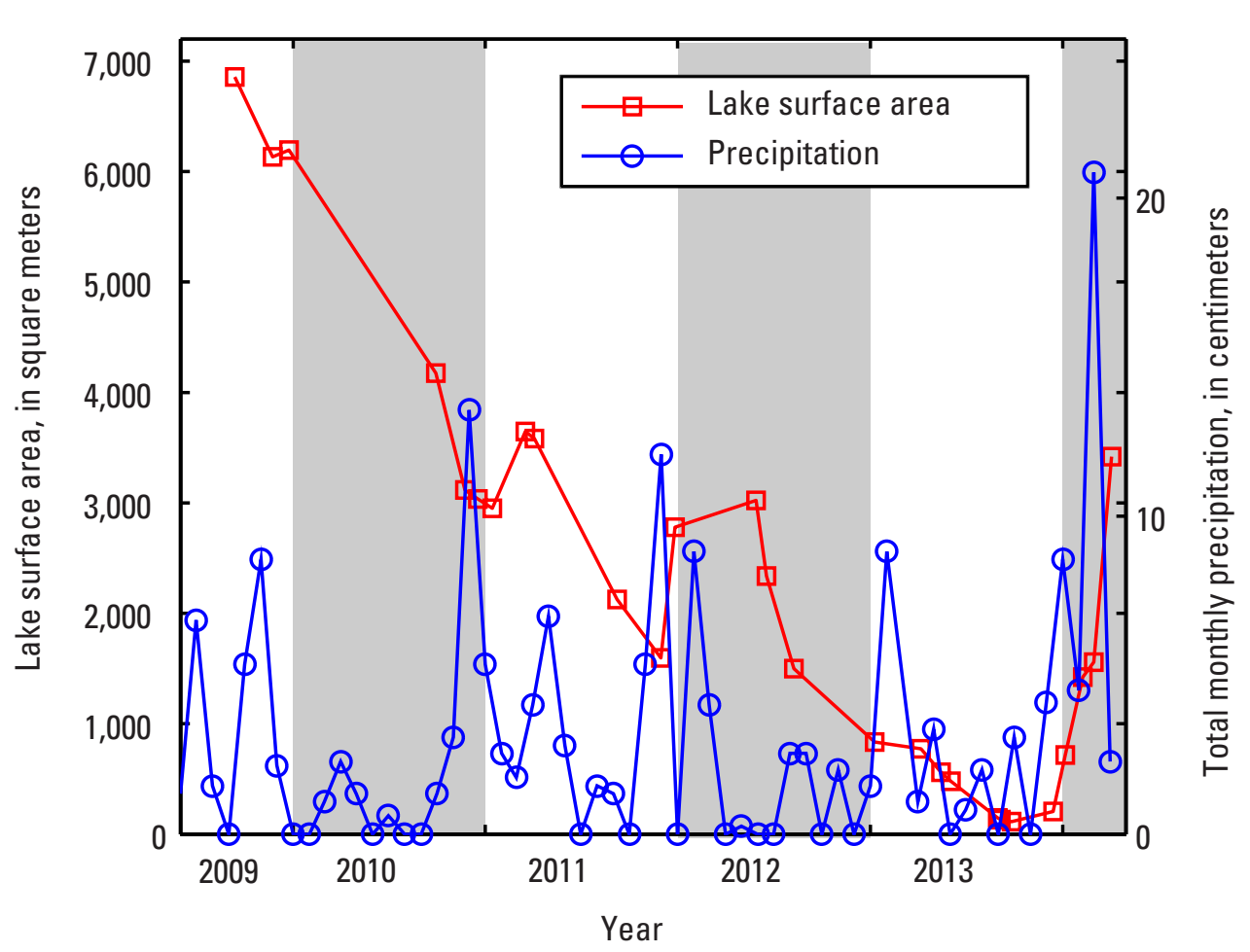

Figure 8. Graph comparing the surface area of Lake Waiau on Mauna Kea volcano, Hawai'i, and precipitation during a decline of the lake, 2009-2014. Transient increases in surface area, in early 2011 and early 2012, are superimposed on the overall decline. These peaks follow seasonal peaks in precipitation. A rebound in lake surface area accompanies increased precipitation in 2014. Also compare the lake surface area trend to figure 9.

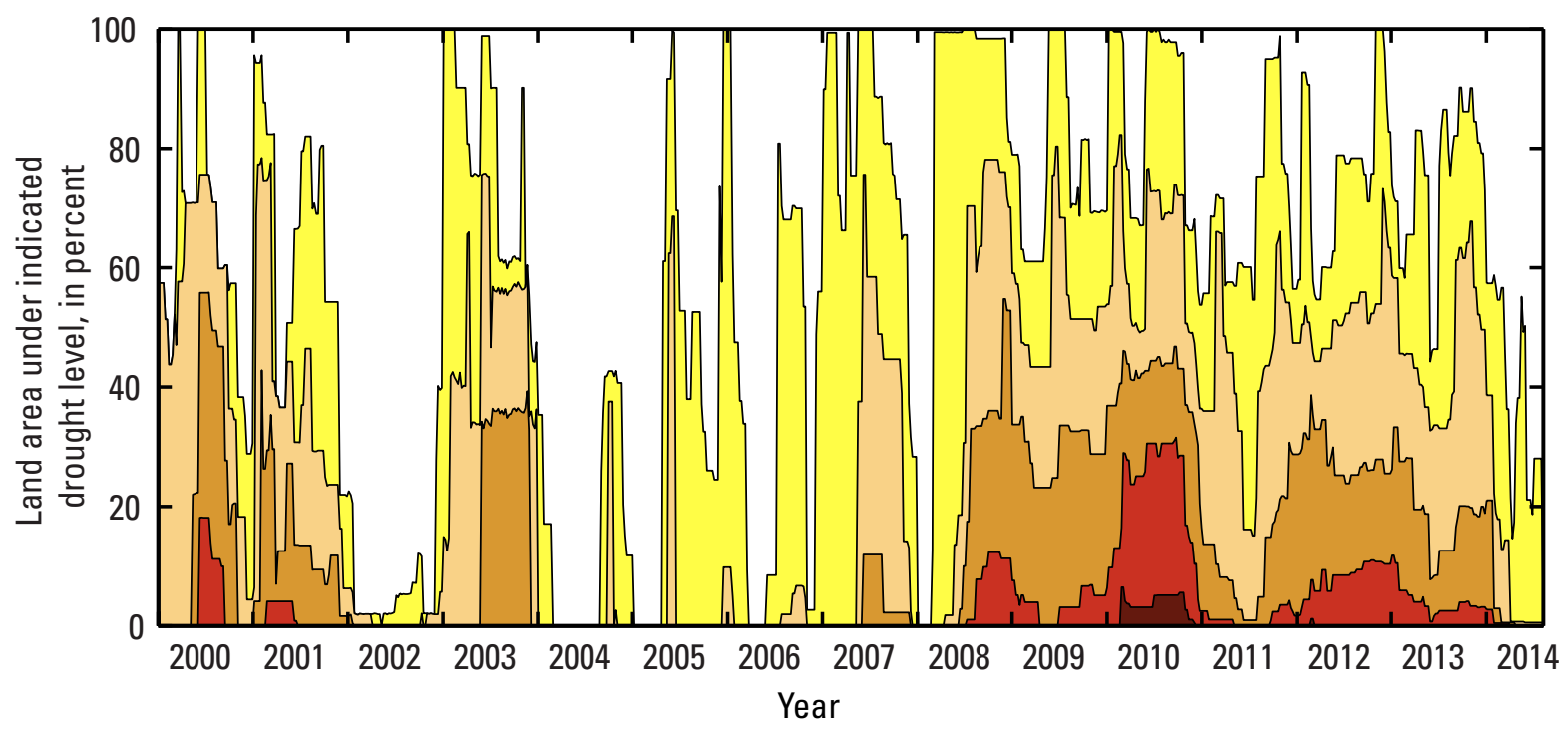

\section{EXPLANATION}

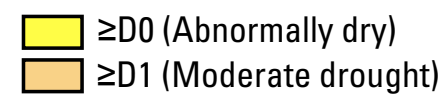
$\geq$ D3 (Extreme drought)

D4 (Exceptional drought)

Figure 9. Graph of drought data for the State of Hawaii from the National Drought Mitigation Center (2014). The graph shows the percent of the State under a particular intensity of drought according to the U.S. Drought Monitor Classification Scheme (see http:// droughtmonitor.unl.edu/AboutUs/ClassificationScheme.aspx). Note that elevated and sustained drought conditions began in 2008, with drought intensities increasing during 2010. Drought levels abated in 2014, at which time the lake area rebounded (see figs. 4 and 8 ). 
when category D4 (exceptional drought) conditions appeared in parts of Hawai' $\mathrm{i}$. These D4 areas were limited to areas on the leeward sides of Kohala and Mauna Kea, close to (but not necessarily encompassing) Lake Waiau, based on the National Drought Mitigation Center maps. Drought levels appear to abruptly drop in early 2014, with the disappearance of even moderate drought across the State, consistent with the increase in precipitation shown in figure 8 .

\section{Discussion}

In the discussion that follows, we summarize our observations of Lake Waiau. We also discuss three possible reasons for the disappearance of the lake.

\section{Summary of Observations}

Observations between 1885 and 2010 suggest that Lake Waiau's typical area for this time period is between 5,000 and $7,000 \mathrm{~m}^{2}$. Beginning in 2010, lake size measurements dropped below this typical range, and by late 2013 the lake had nearly disappeared. By September 2013, the lake consisted of only a small, shallow puddle about $10 \mathrm{~m}$ in size. Our review of historical records provides just one possible observation of the lake being completely dry. Therefore, it appears that the lake's vanishingly small size observed in late 2013 is highly unusual, if not unprecedented, in historical times. The first appearance of unusually low lake-area measurements, in 2010, seems to correspond with an intensification of the recent drought in Hawai' $i$, and the rebound in lake area in early 2014 corresponds in time with heavy winter snowstorms.

\section{Why Did Lake Waiau Nearly Disappear?}

There are three possible explanations for the near-disappearance of Lake Waiau:

1. Draining - The lake has existed as a perched water body because of an impermeable substrate that traps water. Woodcock (1980) and Wolfe and others (1997) believed that fine-grained sediment acts as the impermeable layer; however, Woodcock (1980) suggested that some amount of seepage must occur through this layer to feed the springs at the base of Mauna Kea. The shrinking of the lake might be due some kind of failure in this impermeable layer in 2010, increasing the rate of this seepage. For example, cracking of the sediment layers might permit lake water to leak downward. If the impermeable substrate is permafrost, then melting of the permafrost would permit water to flow downwards.

2. Catchment loss-Woodcock (1980) explained that the lake exists because of some type of impermeable layer surrounding the lake, within $\mathrm{Pu}$ 'uwaiau crater, that allows water falling into the crater to flow into the lake itself, rather than seeping out at the bottom of the crater. The same study proposed that this impermeable layer consists of permafrost. Woodcock (1980) states, "Eventual melting of permafrost . . . may so increase the rate of water loss from Waiau crater as to threaten the continued existence of Lake Waiau as a perennial body of water." Melting of the permafrost would allow precipitation to seep through the crater and never replenish the lake. In this case, the lake's shrinking would be due to evaporation.

3. Drought-Drought is the simplest answer to the lake's near-disappearance, because a severe drought began in Hawai' $i$ around 2008 (National Drought Mitigation Center, 2014). In this case, the rate of precipitation recharge has been insufficient in recent years to balance the loss from evaporation and seepage from the bottom of the lake. Ehlmann and others (2005) state that the lake receives most of its water from sporadic winter storms, and if drought is the main agent driving the lake's disappearance, these storms appear to have been fewer and (or) milder in recent years.

On the basis of our observations, the decline in lake surface area during 2010-2013 is consistent with the recent drought. First, the rate of the lake's shrinking is consistent with evaporative loss alone. The observed rate of lake-level drop during the 2010-2013 period was about 2.7 millimeters per day $\left(\mathrm{mm} \mathrm{day}^{-1}\right)$ (given that the lake is as much as 3 $\mathrm{m}$ deep and that it dropped nearly to zero depth in about 3 years). This level drop rate is consistent with the observed rate of lake-level drop (2.1-3.3 $\mathrm{mm} \mathrm{day}^{-1}$ ) during the 1976-78 drought (Woodcock 1980). It is also consistent with the rates of evaporation from a pan of water $\left(4.9 \mathrm{~mm} \mathrm{day}^{-1}\right)$ measured by Ehlmann and others (2005). Second, the first appearance of unusually low lake-area measurements, in 2010, roughly corresponds with the intensification of the statewide drought, exemplified by the appearance of "exceptional drought" on the leeward sides of Mauna Kea in March 2010 (fig. 9). Monthly precipitation data (fig. $7 B$ ) indicate that there was very little precipitation in early 2010, although not at unprecedented levels. Third, recent precipitation levels on the upper slopes of Mauna Kea seemed to be at unprecedented lows, consistent with the potentially unprecedented nature of the lake's shrinking. Figure $7 A$ shows that the 3 -year mean of precipitation over the last several years dropped to the lowest levels recorded since at least 1940 . Fourth, although it may be tempting to attribute the abrupt onset of the decline shown in figures 4 and 5 to a drainage process, we note that the decline in lake level during drought in 1976-78 shown by Woodcock (1980) was also abrupt, and that the study also shows fairly abrupt seasonal drops in lake level related to dry summers. Lastly, the abrupt rebound in lake area in early 2014 corresponded with heavy winter snowstorms, which is convincing evidence that the decline in lake area was controlled by precipitation. 
Do the recent changes at Lake Waiau have any relation to regional climate change? Giambelluca and others (2008) document a relatively rapid rise in temperatures over the past 30 years throughout Hawai' $i$, consistent with global trends, with stronger warming at higher elevations (although the weather stations in their analysis did not include those on Mauna Kea). Da Silva (2012) analyzed Mauna Kea's summit weather data from 1982 to 2011 and showed a relatively flat trend in temperatures but an overall increase in wind speed. Therefore, Da Silva (2012) and Giambelluca and others (2008) provide conflicting results on whether there has been a warming trend on Mauna Kea's upper slopes, but both Da Silva (2012) and Giambelluca and others (2008) show a recent warming trend on the upper slopes of nearby Mauna Loa. If drought was the main process responsible for the 2010-2013 shrinking of the lake, evaporative loss might have been accelerated by increasing wind speeds documented in Da Silva (2012). The recent drought itself might be a manifestation of the overall decline in precipitation levels in Hawai'i over the past few decades documented by Chu and Chen (2005).

More detailed work on the recent changes could provide useful insights. Researchers at Idaho State University are using lidar (light detection and ranging) and photogrammetric methods to monitor recent changes (Delparte and others, 2014), which represent a step beyond the results shown here because their team can produce accurate estimates of lake volume and depth through time, as opposed to simply lake surface area. These volume estimates, along with the threedimensional characterization of lakebed geometry, would be essential constraints for quantitative hydrologic modeling of the lake, similar to that done by Ehlmann and others (2005). This modeling could provide a more informed analysis and a better determination of the processes driving the recent changes in the lake.

\section{Conclusions}

We used satellite images and aerial photos to document the size of the lake through time. Our time series shows that the lake area first dropped below typical values in 2010, and, by late 2013, the lake had nearly disappeared. On the basis of historical accounts, we believe that this disappearance is highly unusual, if not unprecedented (since 1830). The onset of the lake's shrinking corresponds with an intensification of the recent drought in Hawai' $i$, and precipitation levels after about 2007 were lower than at any other time since at least 1940. These observations, and the abrupt 2014 rebound in lake area, indicate that the lake disappearance is consistent with being caused by the drought. This study demonstrates the effectiveness of satellite imagery for monitoring environmental indicators in sensitive alpine regions.

\section{Acknowledgments}

HVO librarian Jane Takahashi assisted in gaining access to older citations. HVO volunteer Ben Gaddis helped with gathering historical photographs. HVO geologist Frank Trusdell and volunteer Rebecca Rossi participated in the field observations on September 26, 2013, and HVO volunteer Sarah Moore, along with HVO interns Greg Javar and Kanani Pali, assisted with the June 20, 2014, field visit. We thank Donna Delparte (Idaho State University) for discussion on the lake. Fritz Klasner (Office of Mauna Kea Management) provided a critical reading of the manuscript, which improved the paper. We thank Greg Pederson and David Wahl for critical reviews. IKONOS, Quickbird, WorldView, GeoEye, and OrbView satellite images collected by DigitalGlobe, Inc.

\section{References}

Alexander, W.D., 1892, Scientific expedition to Mauna Kea-A week on the summit: The Friend, v. 50, no. 10, p. 74-75.

Baldwin, E.D., 1889, A trip to the summit of Mauna Kea: Hawaiian Annual for 1890, p. 54-58.

Bingham, H., 1847, A residence of twenty-one years in the Sandwich Islands ( $1^{\text {st }}$ ed.): New York, H. Huntington, $616 \mathrm{p}$.

Brigham, W.T., 1909, The volcanoes of Kilauea and Mauna Loa on the island of Hawaii: Memoirs of the Bernice Pauahi Bishop Museum of Polynesian Ethnology and Natural History: Honolulu, Bishop Museum Press, v. 2, no. 4, 222 p., pls. 41-57, 54 p.

Bryan, L.W., 1927, The Mauna Kea Forest Reserve: Paradise of the Pacific, v. 40, no. 12, p. 105-106.

Bryan, L.W., 1939, Lake Waiau of Hawaii: Paradise of the Pacific, v. 51, no. 2, p. 11.

Bryan, W.A., 1915, Natural history of Hawaii: Honolulu, Hawaiian Gazette Co., Ltd., 596 p.

Cao, G., Giambelluca, T.W., Stevens, D.E., and Schroeder, T.A., 2007, Inversion variability in the Hawaiian trade wind regime: Journal of Climate, v. 20, no. 7, p. 11451160, http://dx.doi.org/10.1175/JCLI4033.1.

Chu, P.S., and Chen, H., 2005, Interannual and interdecadal rainfall variations in the Hawaiian Islands: Journal of Climate, v. 18, no. 22, p. 4796-4813, http://dx.doi. org/10.1175/JCLI3578.1. 
Daly, R.A., 1910, Pleistocene glaciation and the coral reef problem: American Journal of Science, ser. 4, v. 30, p. $297-$ 308, http://dx.doi.org/10.2475/ajs.s4-30.179.29710.2475/ ajs.s4-30.179.297.

Da Silva, S.C., 2012, High altitude climate of the Island of Hawai' $i$ : Honolulu, University of Hawai' 1 at Mānoa, M.S. thesis, $110 \mathrm{p}$.

Delparte, D.M., Belt, M., Nishioka, C., Turner, N., Richardson, R., and Ericksen, T., 2014, Monitoring tropical alpine lake levels in a culturally sensitive environment utilizing 3D technological approaches: Arctic, Antarctic, and Alpine Research, v. 46, no. 4, p. 709-718, http://dx.doi. org/10.1657/1938-4246-46.4.709.

Dutton, C.E., 1883, Hawaiian volcanoes, in Powell, J.W., ed., Fourth annual report of the United States Geological Survey to the Secretary of the Interior, 1882-'83: Washington, D.C., U.S. Government Printing Office, p. 75-219.

Ehlmann, B.L., Arvidson, R.E., Jolliff, B.L., Johnson, S.S., Ebel, B., Lovenduski, N., Morris, J.D., Byers, J.A., Snider, N.O., and Criss, R.E., 2005, Hydrologic and isotopic modeling of alpine Lake Waiau, Mauna Kea, Hawai'i: Pacific Science, v. 59, no. 1, p. 1-15.

Giambelluca, T.W., Diaz, H.F., and Luke, M.S.A., 2008, Secular temperature changes in Hawai' $\mathrm{i}$ : Geophysical Research Letters, v. 35, no. 12, L12702, http://dx.doi. org/10.1029/2008GL034377.

Goodrich, J., 1826, Notice of the volcanic character of the Island of Hawaii, in a letter to the editor, and of various facts connected with late observations of the Christian Missionaries in that country, abstracted from a Journal of a Tour around Hawaii, the largest of the Sandwich Islands: American Journal of Science and Arts, ser. 1, v. 11, October, p. 1-36.

Goodrich, J., 1834, Notices of some of the volcanos and volcanic phenomena of Hawaii, (Owyhee,) and other islands in that group: American Journal of Science and Arts, ser. 1, v. 25, January, p. 199-203.

Gregory, H.E., and Wentworth, C.K., 1937, General features and glacial geology of Mauna Kea, Hawaii: Geological Society of America Bulletin, v. 48, no. 12, p. 1719-1742, doi:10.1130/GSAB-48-1719.

Hitchcock, C.H., 1911, Hawaii and its volcanoes (2d ed.): Honolulu, Hawaiian Gazette Co., Ltd., 314 p.; supplement, p. 1-8, 1 pl. [supplement interleaved between p. 306 and 307].

Honolulu Star-Bulletin, 1913, Crest lake is shallow-not bottomless: Honolulu Star-Bulletin, October 20, 1913, p. 7.
Laws, E.A., and Woodcock, A.H., 1981, Hypereutrophication of an Hawaiian alpine lake: Pacific Science, v. 35, no. 3, p. 257-261.

Macdonald, G.A., 1945, Ring structures at Mauna Kea, Hawaii: American Journal of Science, v. 243, no. 4, p. 210-217.

Maly, K., and Maly, O., 2005, Mauna Kea-Ka Piko Kaulana o Ka Āina (Mauna Kea-the famous summit of the land) - A collection of native traditions, historical accounts, and oral history interviews for Mauna Kea, the Lands of Ka' ohe, Humu'ulu and the 'Āina Mauna on the Island of Hawai'i: Report prepared for the Office of Mauna Kea Management, University of Hawai'i-Hilo, accessed September 4, 2014, at http://www.malamamaunakea.org/uploads/culture/ CulturalDocuments/MalyK_2005_MaunaKeaOralHistory_ HiMK67_OMKM033005b_web.pdf.

McCoy, P., 1999, Mauna Kea Science Reserve archaeological site inventory; formal, functional, and spatial attributes, appendix K of Mauna Kea Science Reserve master plan: Hilo, Office of Mauna Kea Management, accessed August 26, 2014, at http://www.hawaii.edu/maunakea/appendix_k. pdf.

Mills, P.R., Lundblad, S.P., Smith, J.G., McCoy, P.C., and Naleimaile, S.P., 2008, Science and sensitivity; a geochemical characterization of the Mauna Kea adze quarry complex, Hawai'i Island, Hawaii: American Antiquity, v. 73, no. 4, p. 743-758.

National Drought Mitigation Center, 2014, Online data, tabular data archive: Lincoln, University of Nebraska, accessed August 26, 2014, at http://droughtmonitor.unl.edu.

Office of Mauna Kea Management (OMKM), 2009, Mauna Kea comprehensive management plan: Hilo, Office of Mauna Kea Management, accessed August 26, 2014, at http://www.malamamaunakea.org/management/ comprehensive-management-plan.

Patrick, M.R., and Delparte, D., 2014, Tracking dramatic changes at Hawaii's only alpine lake: EOS (Transactions American Geophysical Union), v. 95, p. 117-118, http:// dx.doi.org/10.1002/2014EO140001.

Pacific Commercial Advertiser, 1860, Fourth of July on Mauna Kea, Hawaii: Pacific Commercial Advertiser, August 2, p. 2.

Peng, L., and King, J.W., 1992, A late Quaternary geomagnetic secular variation record from Lake Waiau, Hawaii, and the question of the Pacific nondipole low: Journal of Geophysical Research, v. 97, no. B4, p. 4407-4424, http://dx.doi. org/10.1029/91JB03074. 
Pigati, J.S., Zreda, M., Zweck, C., Almasi, P.F., Elmore, D., and Sharp, W.D., 2008, Ages and inferred causes of Late Pleistocene glaciations on Mauna Kea, Hawai'i: Journal of Quarternary Science, v. 23, nos. 6-7, p. 683-702, http:// dx.doi.org/10.1002/jqs.1195.

Porter, S.C., 1979, Quaternary stratigraphy and chronology of Mauna Kea, Hawaii; a 380,000-yr record of mid-Pacific volcanism and ice-cap glaciation; summary: Geological Society of America Bulletin, pt. 1, v. 90, no. 7, p. 609-611, http://dx.doi.org/10.1130/0016-7606(1979)90<609:QSACO $\mathrm{M}>2.0 . \mathrm{CO} ; 2$.

Porter, S.C., 1987, Pleistocene subglacial eruptions on Mauna Kea, chap. 21 of Decker, R.W., Wright, T.L., and Stauffer, P.H., eds., 1987, Volcanism in Hawaii: U.S. Geological Survey Professional Paper 1350, v. 1, p. 587-598.

Pukui, M.K., and Elbert, S.H., 1986, Hawaiian dictionary: Honolulu, University of Hawaii Press.

Sherrod, D.R., Sinton, J.M., Watkins, S.E., and Brunt, K.M., 2007, Geologic map of the State of Hawaii (ver. 1): U.S. Geological Survey Open-File Report 2007-1089, 83 p., 8 map sheets, scale 1:100,000 and 1:250,000, with GIS database, accessed August 26, 2014, at http://pubs.usgs.gov/ of $/ 2007 / 1089 /$.

Stearns, H.T., and Macdonald, G.A., 1946, Geology and ground-water resources of the island of Hawaii: Hawaii (Terr.) Division of Hydrography Bulletin 9, 363 p., 3 folded maps in pocket, scale, pl. 1, 1:125,000; pl. 2, 1:506,880; pl. 3, 1:92,160. (Also available at http://pubs.usgs.gov/misc/ stearns/Hawaii.pdf.)

University of Hawai'i, 2000, Voices and visions of Mauna Kea; Mauna Kea Science Reserve master plan and implementation process summary: Honolulu, University of Hawai'i, 2 v., accessed August 26, 2014, at http://www. hawaii.edu/maunakea/.
Wentworth, C.K., and Powers, W.E., 1941, Multiple glaciation of Mauna Kea, Hawai'i: Geological Society of America Bulletin, v. 52, no. 8, p. 1193-1217, http://dx.doi. org/10.1130/GSAB-52-1193.

Wilkes, C., 1844, Narrative of the United States Exploring Expedition; during the years 1838, 1839, 1840, 1841, 1842 (in five volumes and an atlas): Philadelphia, C. Sherman, v. 1, 455 p.; v. 2, 505 p.; v. 3, 463 p.; v. 4, 574 p.; v. 5, 591 p.

Wilson, W.F., ed., 1922, With Lord Byron at the Sandwich Islands in 1825; being extracts from the MS diary of James Macrae, Scottish botanist: Honolulu, [publisher unknown], 75 p. (Reprinted 1972 by Petroglyph Press, Hilo, Hawaii, 87 p.)

Wolfe, E.W., Wise, W.S., and Dalrymple, G.B., 1997, The geology and petrology of Mauna Kea volcano, HawaiiA study of postshield volcanism: U.S. Geological Survey Professional Paper 1557, 129 p., 4 map sheets in slipcase, scales 1:100,000 and 1:24,000. (Also available at http:// pubs.usgs.gov/pp/1557/report.pdf.)

Woodcock, A.H., Rubin, M., and Duce, R.A., 1966, Deep layer of sediments in alpine lake in the tropical midPacific: Science, new series, v. 154, no. 3749, p. 647-648.

Woodcock, A.H., Furumoto, A.S., Woollard, G.P., 1970, Fossil ice in Hawaii?: Nature, v. 226, no. 5248, p. 873, http:// dx.doi.org/10.1038/226873a0.

Woodcock, A.H., 1974, Permafrost and climatology of a Hawaii volcano crater: Arctic and Alpine Research, v. 6, no. 1, p. 49-62, http://dx.doi.org/10.2307/1550369.

Woodcock, A.H., 1980, Hawaiian alpine lake level, rainfall trends and spring flow: Pacific Science, v. 34, no. 2, p. 195-209. 
Menlo Park Publishing Service Center, California

Manuscript approved for publication May 28, 2015

Edited by James W. Hendley II

Design and layout by Vivian Nguyen 
얼 